SHS Web of Conferences 24, 02013 (2016)

DOI: $10.1051 /$ shsconf/20162402013

(C) Owned by the authors, published by EDP Sciences, 2016

\title{
Efficacy and implementation of ideological and political course in the construction of harmonious psychology of the college students
}

\author{
Xiaohui Wang \\ Department of Social Sciences, School of Humanities, Tianjin Agricultural University, Tianjin, China
}

\begin{abstract}
The ideological and political course is the main channel and the main front for ideological education of the college students, which shoulders the mission of cultivating a higher political quality, as well as a lofty mission and sacred duty of comprehensively and sound developing the scientific outlook on world, outlook on life and values as a qualified socialistic builder. This paper carries out the quantitative analysis about the efficacy and implementation of the course in the construction of the college students' harmonious psychology based on the analytic hierarchy process model. The construction of the college students' harmonious psychology is the function of the ideological and political course. This paper also carries out the quantitative analysis of the reasons for the problems in the development of the college students' physical and mental harmony, and each factor in the construction based on three indicators of the ideological and political course in the construction of the college students' harmonious psychology. On the basis of clarifying the definition of the harmonious psychology, accurately grasping the positioning of the ideological and political course and analyzing the psychological problems of the college students in their growth, this paper finds out the ways and methods to solve the psychological problems of the college students based on the ideological and political course, thus striving to construct a harmonious psychology of the college students, and promoting an overall healthy development of the college students.
\end{abstract}

Keywords: ideological and political; harmonious psychology; fuzzy analysis; hierarchy

\section{INTRODUCTION}

Psychological harmony is a kind of mental adaptive ability of the personnel who can always correctly treat themselves, others and society, and properly treat the difficulty, frustration and honor. And the psychological harmony includes the coordination of cognition, emotion, will and personality, intellectuality of interaction with others, enjoyment of psychological experience, totality of symbolical meanings, stability of duration and comprehensive reflection on other aspects ${ }^{[1]}$. Psychological harmony is a beautiful psychological state. With psychological harmony, the individuals will be calm, optimistic and moderate in distress, and good at regulating their own behavior and heart; in the interpersonal communication, the individuals will be tacit, harmonious and frank to the friends, and lenient in treating others; in life, the individuals will face the reality happily, appreciate good things and accept the challenges of life with a positive attitude ${ }^{[2]}$. A person's growing process is the realization process of the physical and mental harmony.
Harmony is the common ideal of the mankind, the highest realm of psychology, and also an important goal of the ideological and political course in the healthy growth of the college students. The psychological health education is complementary to the ideological and political education of the college students.

\section{PROPER MEANING OF FUNCTION OF IDEOLOGICAL AND POLITICAL COURSE IN THE CONSTRUCTION OF COLLEGE STUDNETS' HARMONIOUS PSYCHOLOGY}

"Psychology" is an important part of the ideological and political course. An important function of the ideological and political course is to promote the psychological harmony of the college students, and an important responsibility of the ideological and political course is the psychological counseling for humanistic care. Under the influence of the complex social and environmental factors, the physical and mental 
development of the contemporary college students is unbalanced, and the values present a diversified tendency. An important task of the ideological and political education is how to effectively carry out work to promote the healthy growth of the college students based on the inner contradictions and various problems of the ideology of the college students ${ }^{[3]}$. The teachers of the ideological and political course should examine the social situation, grasp the pulse of the times and the characteristics of students; furthermore, teachers also should analyze the psychology of the students, capture the entry point of individualized teaching, speak the problems into the heart of the students, and feed the knowledge in the heart of the students; moreover, teachers should solve the real and practical doubts and confusion of the students, and place the promotion of the physical and mental harmony of the college students in the most important and prominent position to grasp the positioning and function of the ideological and political course, which is a fundamental to realize "the construction of courses that are the favorites and benefits to the college students". In the classroom, the teachers' sacred duty of the ideological and political course is to reflect people orientation, focus on the needs of the students, offer necessary psychological counseling and humanistic care to the college students, and strive to achieve the comprehensive development of the college students, which is also a real reflection of the function of the main channel to the ideological and political education of the college students in the ideological and political course.

\section{PERFORMANCE AND REASONS OF PROBLEMS IN PHYSICAL AND MENTAL HARMONIOUS DEVELOPMENT OF COLLEGE STUDENTS}

As the college students have grown up, their physiological development have been mature, and their physical function has been increasingly improved; however, due to their growing experience, the psychological development is lagging behind, and the physical age is inconsistent with the mental age.

(1) Contradictions between independence and dependence. The college students grow up under the care of their parents and elders, who are basically unable to "take care of themselves", completely rely on their parents and lack of the ability to live independently with a strong psychological dependence. After entering a new environment of campus, the college students are transformed from being seriously dependent in the past to entirely independent. This change may cause a lot of incomprehension and maladjustment to the outside world, and they will have ideological and psychological hardship and confusion, resulting in severely psychological panic.

(2) Conflict between ideal and reality. The college students rarely contact with the society, who have a superficial cognition on the outside world, and an illusion of the future life, thus resulting in a serious psychological gap. There is a common saying: "Though the dream is sweet, the reality is very bitter". In particular, the college students are more likely to have a mental state of despair and complaining, and an immature mentality, and be lack of strong will and invincible spirit in case of difficulties in the process of realization of the ideal. For another instance, in the growing process, the college students may change their outlook on life and have a negative withdrawal psychology when they make unremitting and arduous efforts for the ideal, because some other students around them have a good family background and lead a free and comfortable life, flaunting their good jobs and prosperity in the future. In the course of the formation of the world outlook and the outlook on life and values, college students go through and constantly harbor the thinking collision in their heart. At this time, the teachers of the ideological and political course shall timely bear their scared duties, play the role of the ideological and political education which is regarded as the main channel, guide the students to correctly treat the contradictions between ideal and reality, and encourage them to keep their own faith.

(3) Confusion in interpersonal communication. After entering the college, the college students shall be open-minded, easygoing and active to communicate with others, and good at expression in the strange crowd, so as to integrate into the collective life. Such a demand in reality makes different types of students have varying degrees of psychological maladjustment. The teachers of the ideological and political course shall timely provide psychological counseling for the college students to strengthen the humanistic care and eliminate psychological disorders, guide them to get along with others friendly, pursue interpersonal harmony, and adapt to a new stage of life or create a beautiful life.

(4) Pressure of study, life and employment. The flowers in the greenhouse fail to experience the baptism of wind and rain in the outside world. In the campus, there are a large number of talents and outstanding students, who have more excellent learning performance, higher intelligence, more beautiful appearance, superior family background and better artistic capacity. What's more, those who are even the second-generation with parent who is governmental civil servant or the silver spoon. The self-centered superiority at home for some students is suddenly broken up, and these students may be at loose ends after the decrease of the confidence. Moreover, after the change of the previously tense and high-handed policy and the loss of regulation, the passive learning is converted to autonomous learning so that some students feel confused and panic, and lose direction. In addition, some students may have employment pressure from the society, unlike others with a good family 
background who can take the exam of civil servant or public utility. After entering the college, they may confront unemployment after walking out of the college. They do not know the direction in life and have a strong perplexed feeling. At the same time, there are also a variety of certificate examination, grade examination and social activities. It is difficult for the college students to timely transform the mental state that was just liberated from a high pressure of the college entrance examination, so the college students spontaneously arise a feeling of tension and anxiety.

\section{CONSTRUCTION OF HARMONIOUS PSYCHOLOGY BASED ON THE IDEOLOGICAL AND POLITICAL COURSE}

The psychological problems of the college students shall not be simply solved by the psychological counseling and psychological intervention methods. There is a need to make good use of the platform of the ideological and political education, and creatively carry out the education of psychological harmony based on the main front and main channel of the ideological and political education, thus paving a new channel for the construction of the harmonious psychology of the college students ${ }^{[4]}$.

(1) Guide the college students to establish a scientific world outlook, outlook on life and values, and keep a positive attitude towards overcoming the negative psychology. The establishment of correct "three outlooks" is a premise and basis for the college students to have a healthy and harmonious psychology. First, combined with the Basic Principles of Marxism in the ideological and political course, the guidance of the Marxist world outlook and methodology is given to the college students, which can help students to establish a standpoint, viewpoint and method to scientifically perceive and analyze things, dialectically treat problems, enhance the depth and breadth of perceiving things rather than staying in the external appearance, increase the thickness of what they have learned, keep calm in the face of the new environment, new situation and new tasks, capture their own locations, find out a "key stand" for all impetuous and maladjusted circumstance, and achieve psychological harmony. In a related survey of 260 college students, only two people specifically indicate that the ideological and political course is unable to achieve such an effect, and 208 people support this point of view, accounting for $80 \%$. Second, combined with the Ideological and Moral Cultivation and Law Base Course, the guidance establishes a scientific outlook on life and values to the college students, which helps the students establish a positive attitude towards life and pursuing a noble life to serve for people and contributing to society, and keep a positive attitude towards overcoming negative matters and dispersing psychological haze with sunshine, thus coming the fresh air, so the college stu- dents can feel that every day is full and meaningful, keep a positive attitude to integrate with the group and live with others in harmony; what's more, they can shape a brand-new self and bravely create their own beautiful life. In the survey, $90 \%$ of college students support this point of view.

(2) Help the college students strive to achieve interpersonal harmony and grow up happily in the group. People are social beings, and the social network which is the key to success in life is as precious as gold. The education and guidance is given to the college students to cherish the college life, treasure the sentiment of schoolmate, and strive to create a harmonious interpersonal relationship. In life, the students care for each other, and keep a polite and humble, kindhearted and considerate attitude towards others. Just like an old saying goes: "Don't do unto others what you don't want others do unto you". Rather than arrogantly despising others due to their superior conditions, the students get along well with each other, work in unity and help, treat and respect each other as equals.

(3) Stimulate the college students to establish a sense of self-reliance, and clear away the psychological haze. Anything can be possible if a man possesses a powerful heart. We convince that "learning can change one's fate, and knowledge can change his future". We create our happy life and bright future by our efforts, hard work, as well as our wisdom. In the society, there are too many models with successful career: Zhu Cheng, a college student who is a shoeshine and then becomes a sock magnate in Zhejiang Province; a singer who is nicknamed as Xidan girl (a girl who makes living as a street performer in Xidan Station, Beijing) finally performs on the Spring Festival Gala; college student go to class carrying ill stepfather or younger sister for the sake of caring for them... Too many poor people struggle and never bend before the fate. They finally contribute to the society, win the respect of society and prove their own values. In the process of learning knowledge and increase ability, the college students shall also improve the content of the heart and the psychological quality, in order to embrace the whole world with a powerful heart. The college students shall be motivated to train abilities, improve themselves and quality in the beautiful youth's age. As a word of Chinese poetry says like that: "Sharp sword from the sharpening out, plum blossom incense from the cold weather". The college students should establish lofty ideals, bravely confront with the challenges with enough confidence, and strive to be stronger in life. With a positive and powerful heart, low self-esteem, anxiety, confusion and bewilderment will vanish. In the survey, $70 \%$ of college student believe that positive and aggressive life can make the low self-esteem, anxiety, confusion and bewilderment vanished ${ }^{[5]}$.

(4) Educate the college students to establish a sense of responsibility and obligation, and grow up with striving hard. In history, at a historical juncture of the 
Table 1. Analytical hierarchy process system

\begin{tabular}{|c|c|c|}
\hline Target layer & Index at Level I & Index at Level II \\
\hline \multirow{12}{*}{$\begin{array}{l}\text { Efficacy of ideological and polit- } \\
\text { ical course in the construction of } \\
\text { harmonious psychology }\end{array}$} & \multirow{4}{*}{$\begin{array}{l}\text { Harmonious psychology of the college } \\
\text { students is a pattern of manifestation in } \\
\text { the ideological and political course }\end{array}$} & Case analysis (W11) \\
\hline & & Lecture (Special report) (W12) \\
\hline & & Discussion (W13) \\
\hline & & Speech, debate, simulation teaching (W14) \\
\hline & \multirow{4}{*}{$\begin{array}{l}\text { Problems and reasons in physical and } \\
\text { mental harmonious development of } \\
\text { college students }\end{array}$} & $\begin{array}{l}\text { Contradictions between independence and } \\
\text { dependence (W21) }\end{array}$ \\
\hline & & Conflict between ideal and reality (W22) \\
\hline & & $\begin{array}{l}\text { Confusion in interpersonal communication } \\
\text { (W23) }\end{array}$ \\
\hline & & $\begin{array}{l}\text { Learning, life and employment pressure } \\
\text { (W24) }\end{array}$ \\
\hline & \multirow{4}{*}{$\begin{array}{l}\text { Construction of harmonious psycholo- } \\
\text { gy based on the ideological and politi- } \\
\text { cal course }\end{array}$} & $\begin{array}{l}\text { Guide the college students to establish a } \\
\text { scientific world outlook, outlook on life } \\
\text { and values (W31) }\end{array}$ \\
\hline & & $\begin{array}{l}\text { Help the college students strive to achieve } \\
\text { interpersonal harmony and grow up hap- } \\
\text { pily in the group (W32) }\end{array}$ \\
\hline & & $\begin{array}{l}\text { Stimulate the college students to establish } \\
\text { a sense of self-reliance (W33) }\end{array}$ \\
\hline & & $\begin{array}{l}\text { Educate the college students to establish a } \\
\text { sense of responsibility and obligation } \\
\text { (W34) }\end{array}$ \\
\hline
\end{tabular}

national crisis, the college students walk at the forefront of the times, yell for the fate of the country and arouse the patriotic enthusiasm of the whole nation, thus leading the advancement and development of the times. A strong comprehensive national strength is the basic guarantee for standing in the nations of the world. As a generation of youths, the college students should establish a strong sense of responsibility and obligation, and devote themselves to realizing China Dream-great rejuvenation of Chinese nation, and display their talent to reflect their own values on a grand stage of life. The ideological and political course teaches the college students to establish a scientific outlook on world, life and values, and strive to achieve interpersonal harmony and improve the sense of self-reliance. With the responsibility and obligation, the college students can distinguish between the mainstream and tributaries in the society, thus arousing the vitality of the college students, and mobilizing the potential of the college students to forge ahead and move forward positively. And college students should also keep a positive attitude towards overcoming negative matters and have an open and optimistic heart, thus achieving the psychological harmony.

5 INDEX ANALYSIS OF EFFICACY OF IDEOLOGICAL AND POLITICAL COURSE IN CONSTRUCTION OF HARMONIOUS PSYCHOLOGY OF COLLEGE STUDENTS

Combined with the above content, this paper estab- lishes an evaluation and analysis system, as shown in Table 1.

\subsection{Modeling}

First, the object of evaluation is determined, which affects variables by y factor(s). Its factor set is $q$, which is defined as follows:

$$
q=\left(q_{i}, q_{i}, q_{i}, \cdots, q_{i}\right)
$$

Where: $q_{i}(i=1,2,3, \cdots, y)$.

The weight of each variable is different, so the degree of influence is also different in determining the rate of evaluation. Assuming that the weight allocation is $q_{i}$, and $p_{i}=\left(p_{1,} p_{2}, p_{3}, \cdots p_{y}\right)$.

Where: $p_{i}(i=1,2,3, \cdots, y)$ obtains the weight value, $p_{i} \geq 0, \sum_{i=1}^{y} p_{i}=1$

Assuming that each factor $b_{i}$ contains $n$ sub-factor(s), the factor set is $q_{i}=\left(q_{i, 1}, q_{i, 2}, q_{i, 3}, \cdots, q_{i, n}\right)$, and the corresponding weight value is:

$$
p_{i}=\left(p_{i, 1,} p_{i, 2}, p_{i, 3}, \cdots p_{i, n}\right)
$$

For the weight value $p_{i}$ of $q_{i, j}$, based on the common sense, $p_{i, j} \geq 0$ and $\sum_{j=1}^{n} p_{i, j}=1$ 
SSHE 2015

Table 2. Index weight results

\begin{tabular}{|c|c|c|c|}
\hline Criterion layer & Target layer & Result layer & Weight value \\
\hline \multirow{12}{*}{$\begin{array}{l}\text { Efficacy of ideologi- } \\
\text { cal and political } \\
\text { course in the con- } \\
\text { struction of harmo- } \\
\text { nious psychology } \\
\quad \text { W }\end{array}$} & \multirow{4}{*}{$\begin{array}{l}\text { Construction of harmonious psychology of the college } \\
\text { students is the necessity analysis of function of ideo- } \\
\text { logical and political course } \\
0.30\end{array}$} & W11 & 0.29 \\
\hline & & W12 & 0.22 \\
\hline & & W13 & 0.20 \\
\hline & & W14 & 0.29 \\
\hline & \multirow{4}{*}{$\begin{array}{l}\text { Performance and reasons in physical and mental har- } \\
\text { monious development of the college students } \\
0.33\end{array}$} & W21 & 0.25 \\
\hline & & W22 & 0.20 \\
\hline & & W23 & 0.31 \\
\hline & & W24 & 0.24 \\
\hline & \multirow{4}{*}{$\begin{array}{l}\text { Construction of harmonious psychology of college } \\
\text { students based on the ideological and political course } \\
0.37\end{array}$} & W31 & 0.27 \\
\hline & & W32 & 0.25 \\
\hline & & W33 & 0.19 \\
\hline & & W34 & 0.29 \\
\hline
\end{tabular}

Table 3. Evaluation membership value

\begin{tabular}{|l|l|l|l|l|l|}
\hline \multirow{2}{*}{ Evaluation way } & \multicolumn{4}{l|}{ Set score range } \\
\cline { 2 - 6 } & $0-40$ & $40-60$ & $60-80$ & $80-90$ & $90-100$ \\
\hline Very good & 0 & 0 & 0 & 0.05 & 0.95 \\
\hline Good & 0 & 0 & 0.05 & 0.9 & 0.05 \\
\hline Moderate & 0 & 0.05 & 0.9 & 0.05 & 0 \\
\hline Bad & 0.95 & 0.05 & 0 & 0 & 0 \\
\hline
\end{tabular}

The set of evaluation index is:
$h=\left(h_{1}, h_{2}, h_{3}, \cdots, h_{s}\right)$
The corresponding objects of evaluation can be di-
vided into $S$ different levels. Here, assuming that
$h_{1} h_{2}, h_{3}, \cdots, h_{s}$ is the degree of evaluation on the pros
and cons from the top down. According to the compo-
sitional operation of the matrix, we can obtain the
evaluation result of the volleyball achievement of the
corresponding volleyball players, namely: $c=p \cdot r=\left(p_{1}, p_{2}, p_{3}, \cdots p_{y}\right) \cdot\left(r_{1}, r_{2}, r_{3}, \cdots, r_{y}\right)^{T}=\left(c_{1}, c_{2}, c_{3}, \cdots, c_{y}\right)$

Based on the fuzzy set $c$, we can obtain an evaluation rate after normalization processing. $H_{k}=\left\{H_{I}\right\}$, so the rate of the final evaluation result of $H_{K}$ is $k$.

\subsection{Determination of weight}

According to the above table, we know that the evaluation of the teaching quality is determined by a variety of factors, so this paper determines the size of each index weight through combining with the previous experience and applying for the analytical hierarchy process method, with the results as shown in Table 2.

\subsection{Determination of evaluation criterion}

The evaluation results refer to the score range, as shown in Table 3.

\section{ANALYSIS OF EFFICACY OF IDEOLOGICAL AND POLITICAL COURSE IN CONSTRUCTION OF HARMONIOUS PSYCHOLOGY OF COLLEGE STUDENTS}

The above evaluation result:

$K_{11}^{s}=(0.50,0.26,0.20,0.04,0.00)$

By the use of the above formula, this paper respectively obtains the evaluation set of other three subsets corresponding to F1, namely:

$K_{12}^{s}=(0.47,0.32,0.18,0.03,0.00)$

$K_{13}^{s}=(0.11,0.36,0.30,0.21,0.02)$

By the use of the above formula, this paper obtains an evaluation matrix of a single factor of $\mathrm{W} 1$, as shown below:

$K_{1}^{s}=\left[\begin{array}{lllll}0.50 & 0.26 & 0.20 & 0.04 & 0.00 \\ 0.47 & 0.32 & 0.18 & 0.03 & 0.00 \\ 0.11 & 0.36 & 0.30 & 0.21 & 0.02 \\ 0.03 & 0.12 & 0.52 & 0.23 & 0.10\end{array}\right]$

\subsection{Two levels evaluation}

Each index has different degrees of influence on the 
upper level, and different degrees of emphasis on a certain index, so this paper introduces the concept of weight. The weights of three indices at Level I are respectively $W_{1}(0.3), W_{2}(0.2)$ and $W_{3}(0.2)$, then the weights of sub-factors of $F_{1}$ are respectively as follows:

$W_{11}(0.35), W_{12}(0.3), W_{13}(0.25), W_{14}(0.1)$

The corresponding fuzzy sets are as follows:

$A_{1}=(0.4,0.3,0.2,0.1)$

$A_{2}=(0.3,0.3,0.2,0.2)$

$A_{3}=(0.3,0.3,0.2,0.2)$

After integration with the weights and evaluation matrix in the above each process, we can obtain the result of hierarchical evaluation analysis. This paper takes W1 as an example:

$$
\begin{aligned}
P_{1}^{s} & =A_{1} \cdot K_{1}^{s} \\
& =\left(\begin{array}{lll}
0.35,0.28,0.25,0.22,0.1
\end{array}\right)
\end{aligned}
$$

In order to establish the relationship between each index in the ideological and political course, the normalization processing is given to the above result, thus obtaining:

$$
\begin{aligned}
P_{1}^{s} & =\left(\frac{0.35}{1.2}, \frac{0.28}{1.2}, \frac{0.25}{1.2}, \frac{0.22}{1.2}, \frac{0.1}{1.2}\right) \\
& =(0.325,0.267,0.171,0.159,0.085)
\end{aligned}
$$

Similarly, obtaining:

$P_{2}^{s}=(0.263,0.404,0.218,0.111,0.003)$

$P_{3}^{s}=(0.317,0.338,0.1870 .141,0.021)$

Thus, this paper can obtain the form of matrix of the evaluation results of each index at two levels, namely:

$$
K^{s}=\left[\begin{array}{lllll}
0.334 & 0.251 & 0.168 & 0.168 & 0.084 \\
0.251 & 0.416 & 0.228 & 0.105 & 0.000 \\
0.327 & 0.328 & 0.197 & 0.131 & 0.021 \\
0.188 & 0.386 & 0.284 & 0.114 & 0.058
\end{array}\right]
$$

\subsection{Single level evaluation}

Combined with the above process and results, we can adopt same methods and steps to obtain the evaluation results of the first level, assuming that the weight set of the above four factors is:

$$
A=(0.31,0.22,0.28,0.19)
$$

The evaluation results at the corresponding criterion layer are $0.31,0.22,0.28$ and 0.19 . Similarly, the weight evaluation result at the result layer is:

$P^{s}=A \cdot K^{s}$

$$
=(0.310,0.290,0.265,0.185,0.084)
$$

The normalization processing is given to the result, thus obtaining:

$P^{s}=\left(\begin{array}{llll}0.274 & 0.256, & 0.242, & 0.155,0.073\end{array}\right)$

The results show that the analysis and evaluation value is evenly distributed. Based on the evaluation membership value in Table 3 , the evaluation value is excellent and good at the maximum value, and the total value is outstanding based on the efficacy of the ideological and political education in the harmonious psychology under fuzzy evaluation.

\section{CONCLUSION}

Harmony refers to the specific, relative, dynamic and dialectical unity between opposites under a certain condition, and achieves relations of opposition and supplement, mutual promotion and mutual complementation and common development between different matters. This paper analyzes the index of the ideological and political course in the construction of the psychology of the college students based on the fuzzy hierarchical model, and finds that the harmonious psychology of the college students is the weight of the following three indices: a pattern of manifestation of the ideological and political course, reasons of the problems in the physical and mental harmonious development of the college students, and the construction of the harmonious psychology of the college students based on the ideological and political course. This paper also analyzes the efficacy of the ideological and political education in the harmonious psychology under the fuzzy evaluation.

\section{REFERENCES}

[1] Shi Guoxing \& Gao Zhiwen. 2007. Analysis of structure of psychological harmony. Guangming Daily, (7).

[2] Yu Xiaohua. 2006. Cultivation of college students' psychological harmony. Journal of Hebei University of Economics and Trade (Comprehensive Edition), No. 3.

[3] Zhang Sennian. 2006. Thought and exploration of improvement of the effectiveness of ideological and political theory course. Journal of Tsinghua University, 21 (supplement 2): 136.

[4] Xu Jun. 2008. Research on ideological and political education from the perspective of psychology. Shanghai: East China Normal University.

[5] Zhang Zhixiang. 2005. Development trend of foreign moral education and our foothold. Heilongjiang Higher Education Research, (12): 52-55. 